\title{
PERAN PENGETAHUAN ETIKA PADA PERILAKU MANAJEMEN LABA: PERSEPSI AKADEMISI DAN PRAKTISI
}

\author{
Tri Utami \\ Universitas Widya Dharma \\ Jl. Ki Hajar Dewantara, Klaten Utara, Klaten, Jawa Tengah \\ triutami@unwidha.ac.id \\ http://dx.doi.org/10.21460/jrak.2021.172.403
}

\begin{abstract}
ABSTRAK
Ada banyak cara yang dapat dilakukan oleh manajer dan akuntan untuk mempengaruhi pelaporan keuangan dalam suatu unit organisasi, salah satu cara yang dapat dilakukan adalah dengan melakukan manajemen laba, namun Tindakan manajemen laba bisa dikaitkan dengan perilaku etika seseorang. Tujuan pertama dari penelitian ini adalah untuk menguji apakah ada perbedaan keberterimaan etika antara akademisi dan praktisi. Tujuan kedua adalah untuk mengelompokkan beberapa kejadian ekonomi ke dalam faktor manajemen laba. Populasi dalam penelitian ini adalah Praktisi dan Akademisi di bidang akuntansi. Sampel dipilih dengan teknik purposive sampling. Hasil analisis menggunakan Anova membuktikan bahwa terdapat perbedaan keberterimaan etika yang signifikan diantara tiga kelompok responden (akademisi S1, akademisi S2, dan Praktisi). Praktisi menganggap bahwa tindakan manajemen laba sebagai suatu tindakan yang cukup etis, sedangkan akademisi menganggap bahwa perilaku manajemen laba sebagai suatu tindakan yang kurang etis. Hasil analisis menggunakan Principal Component Analysis mengelompokkan beberapa kejadian ekonomi yang sering dilakukan dalam manajemen laba, yaitu melalui penundaan biaya, persediaan, aset tetap dan kebijakan penjualan.
\end{abstract}

Keywords: pengetahuan etika, manajemen laba, sikap

\begin{abstract}
There are several ways to influence financial reporting, one of them is earnings management practice. The first purpose of this study is to test ethical acceptability differences between academics and practitioners. The second purpose of this study is to determine events and transactions into earnings management factor. Population from this study is academics and practitioner in accounting. The sample is chosen using purposive sampling. Statistical test is used in this study is Anova and Principal Component Analysis. This study show that there are significant differences about ethical acceptability between academics and practitioner. Academics assume earnings management as less ethical, while practitioners assume more ethical. Some of event and transaction which used in earnings management are deferred charges, inventory manipulation, property plant and equipment, and sales discretion.
\end{abstract}

Keywords: ethical knowledge, earnings management, attitude 


\section{PENDAHULUAN}

Secara garis besar, tujuan utama didirikannya sebuah unit usaha adalah untuk mencari laba yang sebesar-besarnya. Namun tidak semua unit usaha, terutama perusahaan besar menginginkan laba yang besar, ada kalanya perusahaan melakukan pengaturan terhadap laba yang akan diperoleh (Chung et al., 2005; Litt et al., 2014). Suatu kondisi tertentu mungkin mendorong perusahaan untuk menghasilkan laba yang tinggi, namun ada kondisi lain yang mungkin mendorong perusahaan untuk menghasilkan laba yang rendah, di sisi lain ada suatu kondisi juga yang mendorong agar perusahaan menghasilkan laba yang konsisten, permanen, dan prsisten dari tahun ke tahun (Atwood et al., 2010; Blaylock et al., 2012). Praktek pengaturan laba yang demikian sering disebut dengan manajemen laba. Ditinjau dari sisi akuntansi keperilakuan, praktek manajemen laba bisa saja menimbulkan isu etika, karena pada dasarnya perusahaan bisa mencapai laba di titik 100 misalnya, namun karena ada tujuan tertentu jumlah laba yang bisa dicapai tersebut tidak direalisasikan (overstatement atau understatement), dan bisa saja perusahaan melakukan manipulasi atas informasi akuntansi yang disajikan (BelgasemHussain \& Hussaien, 2020; Heinz et al., 2013; Nekhili et al., 2021; Shafer, 2015).

Praktisi akuntansi (akuntan) mempunyai peran yang penting pada sebuah organisasi dalam menciptakan laporan keuangan yang disajikan secara wajar (Abreu, 2015; Ottoson et al., 2016). Kewajaran atas laporan keuangan ini akan mendorong terciptnya kepercayaan publik terhadap organisasi tertentu. Apabila terjadi tindakan pengaturan laba, maka akan sangat disayangkan sekali, karena tindakan tersebut dapat mengurangi reputasi para akuntan itu sendiri. Pandangan lain juga perlu ditujukan kepada para akademisi.

Seorang akuntan sebelum mereka bekerja tentunya mempunyai kualifikasi pendidikan tertentu di bidang akuntansi. Pendidikan etika bisnis akhir-akhir ini sudah dimasukkan dalam mata kuliah yang harus diambil (Fischer \& Rosenzweig, 1995; Floyd et al., 2013; Kaplan, 2001). Harapannya adalah tertanam perilaku etis sejak awal sebelum mahasiswa masuk dalam dunia kerja. Hal ini mungkin akan menjadi berbeda ketika para mahasiswa sudah masuk dalam dunia kerja. Oleh karena itu menjadi penting untuk menilai keberterimaan etika atas perilaku pengaturan laba pada akademisi dan praktisi (akuntan). Berdasarkan latar belakang di atas, penelitian ini ingin menguji sikap keberterimaan etika para akademisi akuntansi dan praktisi akuntansi terhadap praktek manajemen laba. Apakah ada perbedaan keberterimaan etika antara mahasiswa akuntansi dengan praktisi akuntansi. Selain itu penelitian ini juga ingin menguji kejadian-kejadian ekonomi atau transaksi akuntansi yang manakah yang banyak terjadi praktek manajemen laba.

\section{KAJIAN LITERATUR DAN PENGEMBNAGAN HIPOTESIS}

\section{Laba}

Ada berbagai cara yang dapat digunakan untuk mengukur kualitas laba, misalnya dengan melihat ada atu tidaknya diskresi manajemen dalam setiap kebijakan yang dibuat perusahaan (Beyer et al., 2019; Lo, 2008; Nakashima \& Ziebart, 2015). Cara lain yang dapat digunakan adalah dengan melihat tingkat persistensi laba; jika suatu laba dapat digunakan untuk memprediksi perolehan laba yang akan datang secara akurat juga dapat dikatakan bahwa laba tersebut berkualitas; variabilitas laba yang rendah (tidak naik turun) juga merupakan indicator dari laba yang berkualitas.(Francis et al., 2004; Habib et al., 2013; Hou, 2015). Kerangka Konseptual Laporan Keuangan menyatakan bahwa informasi keuangan yang berkualitas harus memenuhi tiga karakteristik utama, yaitu relevan, reliabilitas, dan komparabilitas. Laba merupakan informasi akuntansi yang sangat berpengaruh, yang digunakan sebagai dasar dalam pengambilan keputusan.

Laba yang berkualitas adalah laba yang dapat digunakan sebagai dasar pengambilan keputusan, yang mempunyai karakteristik relevan, reliabilitas, dan komparabilitas. Penerapan tiga konsep ini mengalami kesulitan, mengingat ketika pengguna laporan kuangan 
membutuhkan reliabilitas, maka relevansi laporan keuangan agak terpinggirkan, jadi konsep relevan dan reliabilitas tergantung pada kejadian-kejadian ekonomi dan transaksitransaksi yang melandasinya (Schipper \& Vincent, 2003)

Laba jika dilihat dari sudut pandang ekonomi dapat diartikan sebagai keuntungan yang didapat oleh seorang pemilik modal dalam suatu kegiatan usahanya. Keuntungan ini tentunya sudah dikurangi dengan biaya operasional. Sementara itu, laba menurut ilmu akuntansi didefinisikan sebagai selisih antara pendapatan dengan biaya-biaya yang dikeluarkan. Laba merupakan kelebihan total pendapatan dibandingkan total biaya. Laba disebut juga pendapatan bersih atau net earnings.

\section{Manajemen Laba}

Manajemen laba terjadi saat manajer menggunakan judgment dalam pelaporan keuangan untuk memberikan gambaran yang kurang sesuai dengan kenyataan ekonomi perusahaan kepada stakeholder (BelgasemHussain \& Hussaien, 2020; Beyer et al., 2019; Chung et al., 2005; Holland \& Jackson, 2004; Lo, 2008; McVay, 2006). Terdapat beberapa motivasi yang memicu manajer untuk melakukan manajemen laba misalnya capital market motivations yang menganggap bahwa manajer melakukan manajemen laba dengan tujuan untuk meningkatkan kinerja harga saham perusahaan (Dou et al., 2016; Wu et al., 2012). Selain itu manajer juga melakukan manajemen laba dengan alasan pasar modal untuk memenuhi ekspektasi analis keuangan (Athanasakou et al., 2009; Cang et al., 2014; Hong et al., 2014).

Insentif dapat menjadi hal lain yang memotivasi manajemen untuk melakukan manajemen laba atau yang sering juga disebut bonus plan hypothesis. Motivasi lain dari melakukan manajemen laba yang diungkapkan (Healy \& Wahlen, 1999) adalah lending contracts atau yang juga dikenal dengan debt covenant hypothesis dan regulatory motivations.

\section{Keberterimaan Etika}

Etika dapat didefinisikan sebagai kebiasaan atau tingkah laku. Etika adalah konsep atau penilaian atau pertimbangan akan suatu tindakan itu benar atau salah, bermoral atau tidak (Fischer \& Rosenzweig, 1995). Secara tidak langsung etika dapat didefinisikan sebagai sebuah pertimbangan moral tentang apa yang harus dilakukan dalam kondisi tertentu, sehingga harus dipilih suatu tindakan yang dirasa benar dan bermoral. Jika seseorang setuju dengan tindakan tersebut, dan ada kesesuaian dengan hati nurani orang tersebut, maka sudah terjadi keberterimaan etika pada individu tersebut (Fischer \& Rosenzweig, 1995; Nekhili et al., 2021)

Praktek manajemen laba merupakan suatu tindakan dimana seseorang melakukan pengaturan terhadap laba yang sebenarnya dapat dicapai oleh manajer, atau sebenarnya tidak dapat dicapai oleh manajer. Laba tersebut bisa saja diperbesar, diperkecil, maupun disamakan dengan laba sebelumnya. Jika hal ini dikaitkan dengan isu etika, maka orang yang mempunyai sensitifitas moral yang tinggi akan merasa bahwa tindakan ini kurang etis. Sensitifitas moral dapat terbentuk melalui pendidikan maupun lingkungan. Salah satu contoh peningkatan sensitifitas moral melalui pendidikan adalah dengan masuknya mata kuliah etika bisnis. Mahasiswa yang sudah mengambil mata kuliah etika bisnis, diharapkan mempunyai sensitifits moral yang tinggi dibandingkan dengan mahasiswa yang belum mengambil mata kuliah etika bisnis. Oleh karena itu hipotesis pertama dalam penelitian ini dinyatakan dengan "ada perbedaan keberterimaan etika antara mahasiswa yang berpengetahuan etika dan mahasiswa yang tidak berpengetahuan etika".

Sensitifitas moral juga dapat terbentuk dari lingkungan tempat tinggal seseorang, misalnya adalah lingkungan kerja. Bisa saja seseorang yang pada awalnya mempunyai sensitifitas moral yang tinggi namun karena adanya tuntutan di lingkungan kerja, maka terjadi peribahan sensitfitas moral yang semula tinggi menjadi rendah. Selain tuntutan pekerjaan, hal lain yang dapat menurunkan sensitifitas moral adalah adanya kepentingan pribadi. Kepentingan pribadi yang dimaksud adalah 
harapan untuk memperoleh insentif jika manajer mampu mencapai kinerja yang ditargetkan. Jika dibandinkan dengan para akademisi, maka akan terjadi perbedaan keberterimaan etika antara akademisi dan praktisi dalam menanggapi praktek manajemen laba. Para akademisi menganggap bahwa manajemen laba merupakan suatu tindakan yang kurang etis, sedangkan para praktisi akan menganggap bahwa manajemen laba merupakan suatu tindakan yang mungkin saja etis. Oleh karena itu hipotesis kedua dalam penelitin ini dinyatakan dengan "ada perbedaan keberterimaan etika pada akademisi maupun praktisi".

Variabel keberterimaan etika diukur dengan instrumen yang pernah digunakan oleh Fischer \& Rosenzweig (1995) dan Bruns \& Merchant (1990). Ada 13 kejadian-kejadian ekonomi yang merupakan cerminan dari tindakan manajemen laba, dengan menggunakan instrumen tersebut, penelitian ini juga bertujuan untuk mengkalsifikasikan ada berapa macam jenis/cara yang dapat digunakan untuk melakukan manajemen laba.

\section{METODA PENELITIAN}

Penelitian ini merupakan penelitian kuantitatif. Data dalam penelitian ini diperoleh dengan metode survey melalui kuesioner yang diberikan kepada akademisi, akademisi yang dimaksud dalam penelitian ini adalah para mahasiswa akuntansi yang telah mengambil mata kuliah etika bisnis dan mata kuliah akuntansi keuangan. Mata kuliah etika bisnis dipilih karena dalam mata kuliah tersebut dipelajari berbagai hal etis yang harus dipertimbangkan ketika melakukan sebuah kegiatan bisnis dan ekonomi, sedangkan mata kuliah akuntansi keuangan merupakan mata kuliah yang didalamnya mencakup seluk beluk penyusunan laporan keuangan dan penyajian informasi akuntansi. Selain mahasiswa, kuesioner juga disebarkan kepada para dosen akuntansi. Jadi responden untuk akademisi terdiri dari mahasiswa dan dosen. Kuesioner juga disebarkan kepada para praktisi akuntansi, yaitu seseorang yang telah bekerja di bidang akuntansi minimal selama 2 tahun.
Variabel keberterimaan etika diukur dengan instrumen yang pernah digunakan oleh (Fischer \& Rosenzweig, 1995) dan (Bruns \& Merchant, 1990). Ada lima skala yang digunakan untuk mengukur seberapa etis tindakan manajemen laba yang dilakukan. Skala 1 menggambarkan bahwa tindakan manajemen laba dipandang tidak etis dan skala 5 menggambarkan bahwa manajemen laba dipandang sebagai suatu tindakan yang etis. Ada 13 item pertanyaan mengenai tindakan manajemen laba yang pada akhirnya dapat digunakan untuk mengetahui keberterimaan etika baik pada akademisi dan praktisi, dan responden diminta untuk menilai 13 tindakan manajemen laba tersebut sebagai tindakan yang etis (skala 5) atau tidakan yang tidak etis (skala $1)$.

Alat uji statistik yang digunakan dalam penelitian ini adalah Principle Component Analysis dan One Way Anova. Principle Component Analysis digunakan untuk mengelompokkan 13 item pertanyaan manajemen menjadi faktor-faktor yang sejenis/yang dipersepsikan sama. Setelah beberapa faktor tersebut diketahui maka akan diuji apakah ada perbedaan pada kelompok tersebut, dan perbedaan pada kelompok akademisi dan praktisi, One-Way Anova digunakan untuk menguji perbedaan pada kelompok-kelompok tersebut.

\section{HASIL DAN PEMBAHASAN}

Responden dalam penelitian ini adalah praktisi akuntansi dan akademisi di bidang akuntansi. Praktisi akuntansi adalah seseorang yang mempunyai latar belakang pendidikan akuntansi dan setiap harinya bekerja di suatu insitusi dan pekerjaannya tidak berhubungan dengan proses belajar mengajar. Praktisi akuntansi lebih ditekankan kepada seseorang yang bekerja dalam suatu perusahaan dan orang tersebut berperan sebagai seorang akuntan, baik junior maupun senior. Akademisi akuntansi yang dimaksud dalam penelitian ini adalah seseorang yang mempunyai latar belakang berpendidikan akuntansi, bekerja dalam suatu institusi tertentu dan pekerjaanya berhubungan dengan proses belajar mengajar di bidang akuntansi. Akademisi dalam penelitian ini lebih 
ditekankan pada mahasiswa, guru akuntansi, maupun dosen akuntansi. Responden dalam penelitian ini berjumlah 105 responden, yang terdiri dari mahasiswa 33 responden, guru/dosen 42 responden, sedangkan praktisi berjumlah 30 responden.

Tabel 1. Kelompok Responden

\begin{tabular}{lc}
\hline Kelompok & Jumlah Responden \\
\hline Mahasiswa & 33 \\
Guru/Dosen & 42 \\
Praktisi & 30 \\
Total & $\mathbf{1 0 5}$ \\
\hline
\end{tabular}

\section{Principal Component Analysis}

Principal Componen Analysis digunakan untuk meringkas beberapa indikator pertanyaan ke dalam beberapa faktor yang mempunyai kesamaan. Beberapa faktor yang terbentuk tersebut selanjutnya bisa disebut sebagai variabel baru. Sebelum dilakukan analisis faktor, harus dilakukan pengujian dulu apakah analisis faktor layak dilakukan atau tidak. UjiKMO merupakan uji pendahuluan yang digunakan sebelum melakukan analisis faktor. Analisi faktor layak dilakukan jika nilai KMO lebih besar dari 0,5 dan nilai signifikansi Bartlett's Test $<0,05$. Tabel 9 dibawah ini menunjukkan nilai KMO 0,646>0,50, dan nilai signifikansi Barlett's Test $0,00<0,05$. Sehingga dapat disimpulkan bahwa analisis faktor layak untuk dilakukan.

Tujuan dilakukannya analisis faktor ini adalah untuk mengelompokkan indikatorindikator manajemen laba ke dalam kelompok yang sejenis. Pengujian ini menggunkan Confirmatory Factor Analysis dengan Varimax Rotation. Hasil pengujian tersebut disajikan pada Tabel 2.

Principal Component Analysis dengan varimax rotation pada Tabel 2 menghasilkan empat faktor yang mempunyai nilai eigen value lebih dari satu, empat faktor tersebut memberikan kontribusi sebesar 75,2\%. Faktor pertama terdiri dari "menunda pencatatatan ke tahun berikutnya, membayar biaya lebih cepat, menunda tagihan masuk dalam jumlah kecil, menunda tagihan masuk dalam jumlah besar".

Tabel 2. Confirmatory Factor Analysis (Varimax Rotation)

\begin{tabular}{llllc}
\hline \multicolumn{1}{c}{ Item Pertanyaan } & \multicolumn{5}{c}{ Component } \\
& $\mathbf{1}$ & $\mathbf{2}$ & $\mathbf{3}$ & $\mathbf{4}$ \\
\hline Schedule-mempercepat & 0.293 & $\mathbf{0 . 6 1 8}$ & 0.462 & 0.161 \\
Defer Exp-mont & 0.296 & 0.248 & 0.122 & $\mathbf{0 . 7 7 7}$ \\
Defer Exp- year & 0.773 & -0.010 & -0.093 & $\mathbf{0 . 4 4 4}$ \\
Supplies-tahun berikutnya & $\mathbf{0 . 6 5 3}$ & 0.278 & 0.138 & 0.150 \\
Pull sells- bebas termin & -0.176 & 0.031 & 0.258 & $\mathbf{0 . 7 6 6}$ \\
Sell Asset-untung & 0.129 & 0.033 & $\mathbf{0 . 7 9 8}$ & 0.181 \\
Prepay-pengeluaran tahun depan & $\mathbf{0 . 7 1 2}$ & 0.269 & 0.293 & -0.233 \\
Inventory-dihapus karena usang & -0.047 & $\mathbf{0 . 5 9 3}$ & 0.693 & 0.032 \\
Inventory- pengembangan produk & 0.044 & $\mathbf{0 . 9 2 9}$ & 0.134 & 0.058 \\
Inventory-dicatat untuk & 0.036 & $\mathbf{0 . 9 1 0}$ & -0.058 & 0.115 \\
memenuhi target & $\mathbf{0 . 4 9 5}$ & 0.010 & 0.641 & 0.274 \\
Defer Exp-small & $\mathbf{0 . 8 7 3}$ & -0.171 & 0.130 & -0.129 \\
Defer exp-large & & & & \\
\hline
\end{tabular}

Faktor kedua terdiri dari "pembebanan biaya pada periode sekarang karena mempercepat penyelesian pekerjaan sebelum jadwalnya, penghapusan persediaan karena dianggap tidak laku, pencatatan persediaan kembali yang digunakan untuk pengembangan 
produk, pencatatan persediaan kembali untuk memenuhi target laba".

Faktor ketiga terdiri dari "keuntungan penjualan aset, dan hanya ada satu indikator saja yaitu keuntungan yang diperoleh dari penjualan asset tetap". Oleh karena itu faktor ketiga diberinama "Aset Tetap". Faktor keempat terdiri dari "penundaan biaya ke bulan berikutnya, penundaan biaya ke tahun berikutnya, memaksimalkan penjualan bebas syarat”. Menurut Bruns and Merchant (1990) ada beberapa cara yang dapat digunakan untuk melakukan manajemen laba, yaitu melalu perlakuan akuntansi dan melalui kebijakan dalam aktifitas operasi. Fischer and Rosenzweig (1995) mengkalsifikasikan tindakan manajemen laba ke dalam empat hal, yaitu manipulasi akuntansi, manipulasi persediaan, manipulasi biaya dan manipulasi pendapatan.

Berdasarkan penelitian yang pernah dilakukan oleh (Bruns \& Merchant, 1990; Fischer \& Rosenzweig, 1995), maka faktorfaktor yang terbentuk dalam penelitian ini diklasifikasikan berdasarkan karakteristikkarakteristik sebagai berikut: Faktor pertama berhubungan dengan penundaan biaya yang telah terjadi atau akan terjadi, oleh karena itu faktor pertama diberi nama "Penundaan Biaya". Faktor kedua berhubungan dengan penghapusan persediaan dan pencatatan kembali persediaan yang dihapus karena ternyata persediaan tersebut mampu dijual, oleh karena itu faktor kedua diberi nama "Perlakuan Persediaan". Faktor ketiga dalam penelitian ini berhubungan dengan penundaan biaya dalam waktu yang singkat dan menekan penjualan sebanyak-banyaknya. Penundaan biaya dalam waktu yang singkat tidak banyak berpengaruh terhadap laba tahunan yang dilaporkan perusahaan, oleh karena itu faktor keempat dalam penelitian ini lebih Ditekankan Pada "Kebijakan Penjualan".

Berdasarkan uraian di atas, maka ada empat faktor yang terbentuk, yaitu penundaan biaya, perlakuan persediaan, aset tetap, dan yang terakhir kebijakan penjualan. Analisis selanjutnya adalah meneliti tingkat keberterimaan etika para akademisi dan praktisi terhadap empat faktor manajemen laba tersebut. Apakah terdapat perbedaan keberterimaan etika antara akademisi dan praktisi.

\section{PEMBAHASAN}

\section{Analisis Perbedaan Keberterimaan Etika}

Seperti yang telah dijelaskan pada bagian sebelumnya, bagian ini akan membahas apakah ada perbedaan keberterimaan etika antara akademisi dan praktisi. Perbedaan keberterimaan etika pada setiap faktor akan dibahas berikut ini. Berdasarkan hasil analisis data menggunakan Anova, diperoleh nilai signifikansi sebesar $0,000<\alpha(0,05)$ pada faktor manajemen laba penundaan biaya, persediaan, dan aset tetap. Hasil ini mengindikasikan bahwa terdapat perbedaan keberterimaan etika pada kelompok akademisi dan praktisi. Hasil ini juga diperjelas oleh Tabel 3.

Tabel 3. Nilai Rata-rata Keberterimaan Etika

\begin{tabular}{lllll}
\hline Kelompok & $\begin{array}{l}\text { Tunda } \\
\text { Biaya }\end{array}$ & $\begin{array}{l}\text { Perse- } \\
\text { diaan }\end{array}$ & $\begin{array}{l}\text { Aset } \\
\text { Tetap }\end{array}$ & $\begin{array}{l}\text { Pen- } \\
\text { jualan }\end{array}$ \\
\hline Guru/Dosen & 10,29 & 12,36 & 2,86 & 6,07 \\
Mahasiswa & 14,73 & 13,00 & 3,18 & 6,00 \\
Praktisi & 12,90 & 14,40 & 3,40 & 6,10 \\
Sig. & $\mathbf{0 , 0 0}$ & $\mathbf{0 , 0 2}$ & $\mathbf{0 , 0 4}$ & $\mathbf{0 , 9 7}$ \\
\hline
\end{tabular}


Pada Tabel 3 diperoleh nilai rata-rata dari faktor penundaan biaya untuk kelompok akademisi sebesar 10,29 untuk dosen dan 14,73 untuk mahasiswa; sedangkan nilai rata-rata untuk Praktisi sebesar 12,90 dan dengan menggunakan analisis Anova terdapat perbedaan yang signifikan pada tiga kelompok tersebut (sig. $0,00<\alpha 0,05$ ). Keberterimaan etika diukur menggunakan skala likert 1-5 "Sangat Tidak Etis-Sangat Etis", semakin besar nilai rata-rata keberterimaan etika menandakan bahwa tindakan manajemen laba dianggap semakin etis. Pada kelompok Guru/Dosen mempunyai nilai rata-rata keberterimaan etika sebesar 10,29 dan nilai keberterimaan etika praktisi sebesar 12,90. Hal ini menandakan bahwa praktisi menganggap perilaku manajemen laba yang dilakukan melalui penundaan biaya sebagai suatu tindakan yang etis, sedangkan kelompok Guru/Dosen menganggap sebagai tindakan yang kurang etis. Faktor perlakuan persediaan kelompok Guru/Dosen mempunyai nilai rata-rata keberterimaan etika sebesar 12,37; kelompok mahasiswa mempunyai nilai rata-rata sebesar 13,00 dan nilai rata-rata keberterimaan etika praktisi sebesar 14,40. Nilai keberterimaan etika praktisi lebih besar daripada akademisi. Pengujian dengan Anova juga menunjukkan adanya perbedaan yang signifikan pada tiga kelompok tersebut (sig. 0,02< $<0,05$ ). Hasil ini mengindikasikan bahwa praktisi menganggap perilaku manajemen laba yang dilakukan melalui persediaan sebagai suatu tindakan yang etis, sedangkan grup Guru/Dosen menganggapnya sebagai tindakan yang kurang etis.

Faktor aset tetap pada kelompok Guru/Dosen mempunyai nilai rata-rata keberterimaan etika sebesar 2,86; kelompok mahasiswa sebesar 3,18 dan nilai rata-rata keberterimaan etika praktisi sebesar 3,40. Hasil uji Anova juga menunjukkan ada perbedaan yang signifikan diantara tiga kelompok tersebut (sig. $0,04<\alpha 0,05$ ). Hasil ini menandakan bahwa kelompok mahasiswa menganggap perilaku manajemen laba yang dilakukan melalui aset tetap sebagai suatu tindakan yang etis, disusul oleh praktisi yang merasa agak kurang etis dan pada kelompok Guru/Dosen menganggap sebagai tindakan yang kurang etis.
Walaupun demikian, tetap terdapat perbedaan keberterimaan etika yang signifikan di atara ketiga kelompok tersebut, dan dibandingkan dengan praktisi, kelompok Guru/Dosen menganggap tindakan manajemen laba melalui aset tetap sebagai tindakan yang kurang etis.

Faktor mnajemen laba yang terakhir adalah kebijakan penjualan, hasil pengujian menunjukkan bahwa tidak ada perbedaan yang signifikan diantara kelompok dosen, mahasiswa, dan praktisi. Jika dilihat dari nilai rata-rata yang ada pada Tabel 3, tetap menunjukkan bahwa praktisi menganggap tindakan manajemen laba melalui kebijakan penjualan sebagai tindakan yang etis, sedangkan kelompok mahasiswa atau dosen menganggapnya kurang etis. Hal ini ditandai dengan perbedaan nilai rata-rata keberterimaan etika (semakin tinggi nilainya berarti menganggap tindakan tersebut semakin etis).

Hipotesis pertama dalam penelitian ini dinyatakan dengan "ada perbedaan keberterimaan etika antara mahasiswa yang berpengetahuan etika dan mahasiswa yang tidak berpengetahuan etika". Berdasarkan analisi di atas, dapat disimpulkan bahwa memang terdapat perbedaan keberterimaan etika antara mahasiswa dan dosen, atau dengan kata lain pengetahuan etika yang dimiliki oleh dosen dan mahasiswa berbeda, sehingga keberterimaan etika juga menunjukkan hasil yang berbeda, Dosen/mahasiswa S2 menilai tindakan manajemen laba sebagai tindakan yang kurang etis, sedangkan mahasiswa menganggapnya sebagai tindakan yang etis. Oleh karena itu hipotesis pertama yang diajukan dalam penelitian ini terdukung.

Hipotesis kedua dalam penelitian ini dinyatakan dengan "ada perbedaan keberterimaan etika antara akademisi maupun praktisi". Hasil pengujian menunjukkan bahwa keberterimaan etika para praktisi selalu mempunyai nilai yang paling tinggi dibandingkan dengan mahasiswa atau dosen, yang dapat diartikan bahwa para praktisi menganggap tindakan manajemen laba sebagai tindakan yang etis, sedangkan akdemisi menganggap manajemen laba sebagai tindakan yang kurang etis. Oleh karena itu hipotesis kedua dalam penelitian ini terdukung. 


\section{SIMPULAN, KETERBATASAN, DAN SARAN}

\section{SIMPULAN}

Tujuan pertama dari penelitian ini adalah untuk menguji apakah ada pengaruh pengetahuan etika terhadap keberterimaan etika. Semakin besar nilainya menunjukkan bahwa kelompok tersebut semakin menerima tindakan manajemen laba. Hasil pengujian menunjukkan bahwa mahasiswa S1 mempunyai nilai rata-rata keberterimaan etika yang lebih besar daripada mahasiswa S2, sehingga dapat disimpulkan bahwa mahasiswa S1 merasa bahwa tindakan manajemen laba sebagai suatu tindakan yang etis, sedangkan mahasiswa S2 menganggap tindakan manajemen laba sebagai suatu tindakan yang kurang etis.

Sedangkan keberterimaan etika antara akademisi (dosen dan mahasiswa) dengan praktisi menunjukkan bahwa terdapat perbedaan keberterimaan etika antara praktisi dan akademisi. Praktisi cenderung memandang bahwa tindakan manajemen laba sebagai suatu tindakan yang etis, sedangkan akademisi menganggap bahwa tindakan manajemen laba sebagai suatu tindakan yang kurang etis.

Tujuan kedua dari penelitian ini adalah untuk meringkas beberapa indikator manajemen laba ke dalam faktor-faktor manajemen laba. Tigabelas indikator manajemen laba yang ada (pembebanan biaya pada periode sekarang karena mempercepat penyelesian pekerjaan sebelum jadwalnya, penundaan biaya ke bulan berikutnya, penundaan biaya ke tahun berikutnya, menunda pencatatatan ke tahun berikutnya, memaksimalkan penjualan bebas syarat, memaksimalkan produksi barang, menjual aset tetap, membayar biaya lebih cepat, penghapusan persediaan karena dianggap tidak laku, pencatatan persediaan kembali yang digunakan untuk pengembangan produk, pencatatan persediaan kembali untuk memenuhi target laba, menunda tagihan masuk dalam jumlah kecil, menunda tagihan masuk dalam jumlah besar) setelah dilakukan uji validitas ternyata ada satu indikator yang tidak valid (memaksimalkan produksi barang), oleh karena itu indikator tersebut dikeluarkan dari analisis. Setelah dilakukan uji validitas dan reliabilitas, maka selanjutnya dilakukan uji Principal Component Analysis untuk membentuk faktor-faktor manajemen laba. Hasil analisi menggunakan Confirmatory Factor Analysis dengan Varimax Rotation menghasilkan 4 faktor, yaitu:

Faktor pertama diberi nama faktor penundaan biaya yang terdiri dari menunda pencatatatan ke tahun berikutnya, membayar biaya lebih cepat, menunda tagihan masuk dalam jumlah kecil, menunda tagihan masuk dalam jumlah besar. Faktor Kedua diberi nama perlakuan persediaan yang terdiri dari pembebanan biaya pada periode sekarang karena mempercepat penyelesian pekerjaan sebelum jadwalnya, penghapusan persediaan karena dianggap tidak laku, pencatatan persediaan kembali yang digunakan untuk pengembangan produk, pencatatan persediaan kembali untuk memenuhi target laba. Faktor ketiga diberi nama aset tetap yang hanya terdiri dari menjual aset tetap dan memperoleh keuntungan.Faktor keempat diberi nama KEBIJAKAN PENJUALAN yang terdiri dari penundaan biaya ke bulan berikutnya, penundaan biaya ke tahun berikutnya, memaksimalkan penjualan bebas syarat.

\section{KETERBATASAN}

Penelitian ini mengalami keterbatasan pada ukuran sampel yang digunakan terlalu sedikit, sehingga kemampuan untuk dapat digeneralisasikan menjadi kurang kuat.

\section{SARAN}

Untuk penelitian selanjutnya diharapkan mampu menggunakan ukuran sampel yang lebih banyak sehingga mampu menunjukkan keterwakilan dari berbagai daerah secara proporsional. 


\section{DAFTAR REFERENSI}

Abreu, R. (2015). Accounting for citizenship: The role of accountant. Procedia Economics and Finance, 26, 933-941.

Athanasakou, V. E., Strong, N. C., \& Walker, M. (2009). Earnings management or forecast guidance to meet analyst expectations? Accounting and Business Research, 39(1), 3-35.

Atwood, T., Drake, M. S., \& Myers, L. A. (2010). Book-tax conformity, earnings persistence and the association between earnings and future cash flows. Journal of Accounting and Economics, 50(1), 111-125.

Belgasem-Hussain, A. A., \& Hussaien, Y. I. (2020). Earnings management as an ethical issue in view of Kohlberg's theory of moral reasoning. Journal of Financial Crime.

Beyer, A., Guttman, I., \& Marinovic, I. (2019). Earnings management and earnings quality: Theory and evidence. The accounting review, 94(4), 77-101.

Blaylock, B., Shevlin, T., \& Wilson, R. J. (2012). Tax avoidance, large positive temporary book-tax differences, and earnings persistence. The accounting review, 87(1), 91-120.

Bruns, W. J., \& Merchant, K. (1990). The dangerous morality of managing earnings. Management accounting, 72(2), 22-25.

Cang, Y., Chu, Y., \& Lin, T. W. (2014). An exploratory study of earnings management detectability, analyst coverage and the impact of IFRS adoption: Evidence from China. Journal of Accounting and Public Policy, 33(4), 356-371.

Chung, R., Firth, M., \& Kim, J.-B. (2005). Earnings management, surplus free cash flow, and external monitoring. Journal of business research, 58(6), 766-776.

Dou, Y., Hope, O. K., Thomas, W. B., \& Zou, Y. (2016). Individual large shareholders, earnings management, and capital-market consequences. Journal of Business Finance \& Accounting, 43(7-8), 872-902.
Fischer, M., \& Rosenzweig, K. (1995). Attitudes of students and accounting practitioners concerning the ethical acceptability of earnings management. Journal of Business Ethics, 14(6), 433444.

Floyd, L. A., Xu, F., Atkins, R., \& Caldwell, C. (2013). Ethical outcomes and business ethics: Toward improving business ethics education. Journal of Business Ethics, 117(4), 753-776.

Francis, J., LaFond, R., Olsson, P. M., \& Schipper, K. (2004). Costs of equity and earnings attributes. The accounting review, 79(4), 967-1010.

Habib, A., Bhuiyan, B. U., \& Islam, A. (2013). Financial distress, earnings management and market pricing of accruals during the global financial crisis. Managerial Finance.

Healy, P. M., \& Wahlen, J. M. (1999). A review of the earnings management literature and its implications for standard setting. Accounting horizons, 13(4), 365-383.

Heinz, P., Patel, C., \& Hellmann, A. (2013). Some theoretical and methodological suggestions for studies examining accountants' professional judgments and earnings management. Advances in accounting, 29(2), 299-311.

Holland, K., \& Jackson, R. H. (2004). Earnings management and deferred tax. Accounting and Business Research, 34(2), 101-123.

Hong, Y., Huseynov, F., \& Zhang, W. (2014). Earnings management and analyst following: A simultaneous equations analysis. Financial Management, 43(2), 355-390.

Hou, Y. (2015). The role of diversification in the pricing of accruals quality. Review of Accounting Studies, 20(3), 10591092.

Kaplan, S. E. (2001). Further evidence on the ethics of managing earnings: an examination of the ethically related judgments of shareholders and nonshareholders. Journal of Accounting and Public Policy, 20(1), 27-44.

Litt, B., Sharma, D., \& Sharma, V. (2014). Environmental initiatives and earnings 
management. Managerial Auditing Journal.

Lo, K. (2008). Earnings management and earnings quality. Journal of Accounting and Economics, 45(2-3), 350-357.

McVay, S. E. (2006). Earnings management using classification shifting: An examination of core earnings and special items. The accounting review, 81(3), 501-531.

Nakashima, M., \& Ziebart, D. A. (2015). Did Japanese-SOX have an impact on earnings management and earnings quality? Managerial Auditing Journal.

Nekhili, M., Javed, F., \& Nagati, H. (2021). Audit Partner Gender, Leadership and Ethics: The Case of Earnings
Management. Journal of Business Ethics, 1-28.

Ottoson, E., Nikitina-Kalamae, M., \& Gurvits, N. (2016). The Role of Accountant in the Estonian Enterprise. Central European Business Review, 5(2), 47.

Schipper, K., \& Vincent, L. (2003). Earnings quality. Accounting horizons, 17, 97110.

Shafer, W. E. (2015). Ethical climate, social responsibility, and earnings management. Journal of Business Ethics, 126(1), 43-60.

Wu, S.-W., Lin, F., \& Fang, W. (2012). Earnings management and investor's stock return. Emerging Markets Finance and Trade, 48(sup3), 129-140.

\section{Copyrights}

Copyright for this article is retained by the author(s), with first publication rights granted to the journal.

This is an open-access article distributed under the terms and conditions of the Creative Commons Attribution license (http://creativecommons.org/licenses/by/4.0/). 